\title{
China: Climate Leader and Villain
}

\author{
Michal Meidan
}

\section{China's Changing Energy Landscape}

Since China's reform and opening up in 1978, the country has undergone a profound transformation: The Chinese economy in 1978, as measured in Gross Domestic Production (GDP) stood at $\$ 150$ billion (current US\$ according to the World Bank (2019), and was half the size the Italian economy. Three decades later, China's economy is the second largest in the world and its per capita GDP has grown by nearly 24 times from 1978 to 2017 . Even though income inequality has increased dramatically, the country has all but eradicated extreme poverty, with the share of China's population living in extreme poverty (according to the World Bank definition) plummeting from $90 \%$ in 1971 to less than $2 \%$ by 2013 .

Significantly, in 1980, agriculture was a larger part of the Chinese economy than industry and services, but it now accounts for under $10 \%$, while the service sector is approaching $40 \%$, and industry accounts for the lion's share of economic activity. Urbanisation has therefore been a defining feature of China's economic transformation, with the rural population, which accounted for roughly $85 \%$ of China's population on the eve of China's reform and opening up, now down to around $40 \%$ (World Bank 2019).

\subsection{A Voracious Appetite for Fossil Fuels}

Fuelling the country's rapid industrialisation and urbanisation process is a voracious appetite for energy, with primary energy consumption increasing sevenfold, from just under 400 million tonnes oil equivalent (toe) in 1978 (BP 2019), to 3.27 billion toe

\footnotetext{
M. Meidan ( $\square)$

Oxford Institute of Energy Studies (OIES), Oxford, England

e-mail: michal.meidan@ oxfordenergy.org 


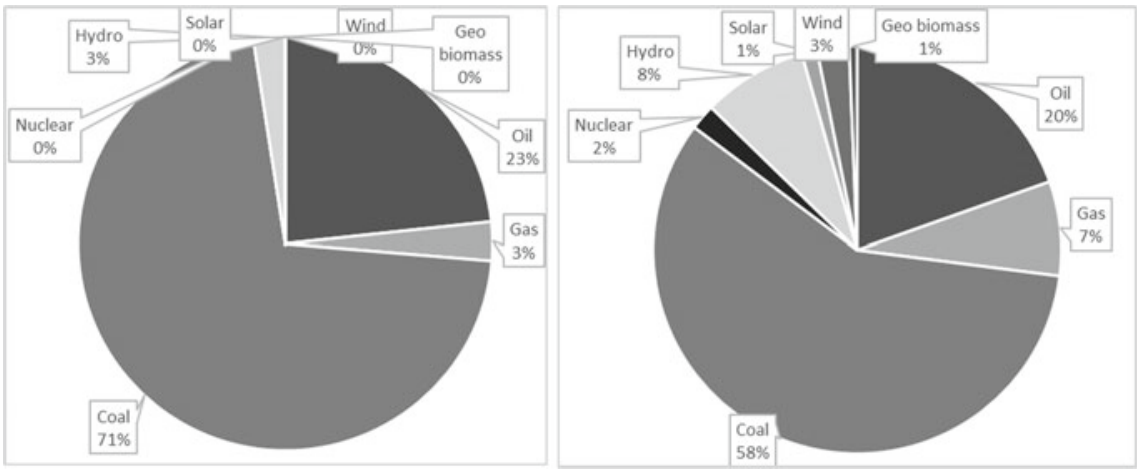

Fig. 1 China's energy mix 1978, 2018. While China's energy mix still relies heavily on coal, it has become much more diverse over the course of the last four decades. Source BP

in 2018. Domestically produced coal accounted for $70 \%$ of the energy mix in 1978 , alongside oil which accounted for another $23 \%$. In the late 1970s, China consumed a mere 17\% of global coal (BP 2019), but by 2018, however, China burned 1.9 billion toe of coal, half of the coal used worldwide (see Fig. 1).

In light of China's heavy reliance on coal, the country has, since 2006, become the world's largest emitter of carbon dioxide $\left(\mathrm{CO}_{2}\right)$. In 2018, according to the BP Statistical Review (BP 2019), the country accounted for $28 \%$ of global $\mathrm{CO}_{2}$ emissions-more than the US and the EU combined, with coal accounting for an estimated $70 \%$ of energy-related $\mathrm{CO}_{2}$ emissions (Myllyvirta 2019).

China's carbon footprint has also expanded due to the country's oil demand, which has tripled over the past 20 years, from 4.1 million barrels per day (mb/d) in 1998, to $13.5 \mathrm{mb} / \mathrm{d}$ in 2018 (BP 2019). Urbanisation and rising incomes have increased the number of passenger vehicles on China's roads. Indeed, in 2010, China's passenger vehicle park was estimated at 55 million vehicles, but in 2018, it counted 199 million. Still, there are currently only 150 vehicles per 1,000 persons in China, compared to around 600 vehicles per 1,000 persons in France and Germany, and as the middle class continues to grow wealthier and buy cars, oil demand is set to rise further. That said, China's ambitious programme to electrify its fleet could displace some oil demand growth in the future, allowing the country also to tackle local air pollution problems. But with a power sector heavily reliant on coal, until China decarbonises the power sector, electric vehicles only displace the problem. At the same time, air travel and demand for consumer goods (and the freight to transport them around the country) have all contributed to the surge in China's oil demand growth and will continue to fuel the country's reliance on crude oil. But with limited domestic reserves, China has become dependent on imported crude, leaving it vulnerable to geopolitical disruptions in producer countries across the globe, and especially in the Middle East, which supplies just under half of China's total imports (see Fig. 2).

This surge in China's external exposure to natural resources has been just as rapid as its economic boom: In 1993, China became a net importer of oil for the first time, 


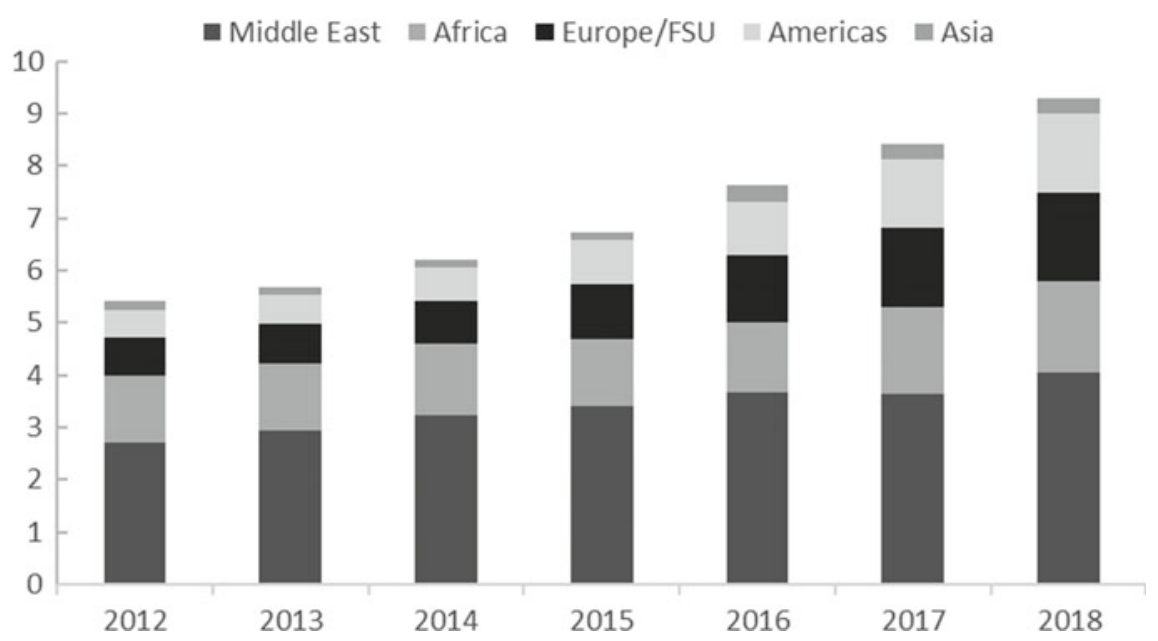

Fig. 2 China's crude oil imports by region, mb/d. Source China Customs

and 10 years later, it was importing 5.6 million barrels per day $(\mathrm{mb} / \mathrm{d})$, roughly the equivalent of Iranian and Iraqi oil production combined that year. By 2018, China's crude oil imports reached $9.2 \mathrm{mb} / \mathrm{d}$.

\subsection{Changing Policy Priorities}

Over the course of the past four decades, since the 'reform and opening up' and especially since the country's accession to the World Trade Organisation (WTO) in 2001, to accommodate China's rapid economic development, energy policy was geared first and foremost towards ensuring ample supplies: to keep factories churning, to deliver energy from producer hubs to consumer centres, and to keep the rising numbers of urban homes warm in winter and cool in summer. But as China's appetite for energy continued to grow and outstrip its domestic production, the country's policymakers began fretting about rising dependence on waterborne flows of commodities and the US's ability to curb supplies via maritime routes (Downs 2019; Meidan 2014). Chinese companies, with government support, embarked on costly M\&As and overseas infrastructure investments, hoping to secure a footprint across the energy value chain. Producer countries from the Middle East through to the Americas saw new opportunities to produce and sell commodities to China, and also to attract investments in infrastructure, even in conflict-torn countries.

China's concerns about import dependence were gradually also compounded by the rising toll of environmental degradation (Meidan et al. 2009). China is home to around $20 \%$ of the world's population but has five to seven percent of freshwater resources and under $10 \%$ of the world's arable land (Ely et al. 2019). China's mega 
deltas are particularly vulnerable to rising sea levels, while hazardous smog in densely populated cities - from industrial activities and road transport-is driving demand for the government to tackle air pollution (Ramaswami et al. 2017). Moreover, health problems due to air pollution are estimated to have led to the loss of about 133 million workdays in China in 2007, or 1.34\% of real GDP (ChinaPower 2016).

Yet unlike many developed economies, that began to regulate air pollution after their de-industrialisation was underway, the Chinese economy continues to grow and industrialise, leaving the government to grapple with the need to protect its environment while also ensuring affordable and secure sources of energy. The need to diversify the domestic energy mix and ensure more sustainable fuels for growth has coincided with a broader desire to shift the country's economic structure away from industrial-led growth towards a consumption-driven development path. Environmental protection which was once seen as a costly impediment to growth has become both a social necessity and an industrial opportunity.

This change in priorities was reflected in the 12th Five-Year Plan (12th FYP, spanning 2011-2015), in which the government set out for the first time binding targets for a $16 \%$ reduction in energy consumption per unit of GDP, an $8 \%$ reduction in sulphur dioxide $\left(\mathrm{SO}_{2}\right)$ emissions and a $10 \%$ reduction in nitrogen oxide (NOx) emissions by 2015, from 2010 levels. As a result, PM2.5 monitoring efforts intensified with the government setting more stringent targets for heavily polluted regions. The 12th FYP also incorporated a number of specific measures to shut down heavily polluting industrial facilities and expand the use of clean energy, including natural gas. Against this backdrop, China introduced its first 'Airborne Pollution Prevention and Control Action Plan' in 2013 (Action Plan 2013), which recognised coal as a key driver of air pollution and sought to limit its use (ChinaPower 2016).

The Action Plan 2013 established mid- to long-term targets for reducing total coal consumption and cutting its share of the energy mix (Miyamoto and Ishiguro 2018), replacing industrial coal furnaces with natural gas. Gas demand, which has long played second fiddle to both the coal and oil industries, began to surge on the back of the coal-to-gas switch. In the early 2000s, natural gas was largely used as feedstock in industry and only played a marginal role in the power sector, where coal remains the dominant fuel. While this still holds true for the power sector, the coal-to-gas switch as mandated by the Action Plan 2013 led to a strong surge in industrial and commercial gas consumption. As a result, China's natural gas demand went from $177 \mathrm{bcm}$ in 2013 to $280 \mathrm{bcm}$ in 2018 (Fig. 3) but the strong uptick in demand also led to an increased dependence on imported gas, mainly liquefied natural gas (LNG).

But with global oil and gas prices falling on rising US shale production, supply security become a secondary concern in Beijing. Moreover, in the early Trump years, increased oil and gas imports from the US were touted as a potential way of evening out some of the US-China trade deficit, with Chinese traders increasing their purchases of US crude oil and looking to sign long-term LNG contracts. 


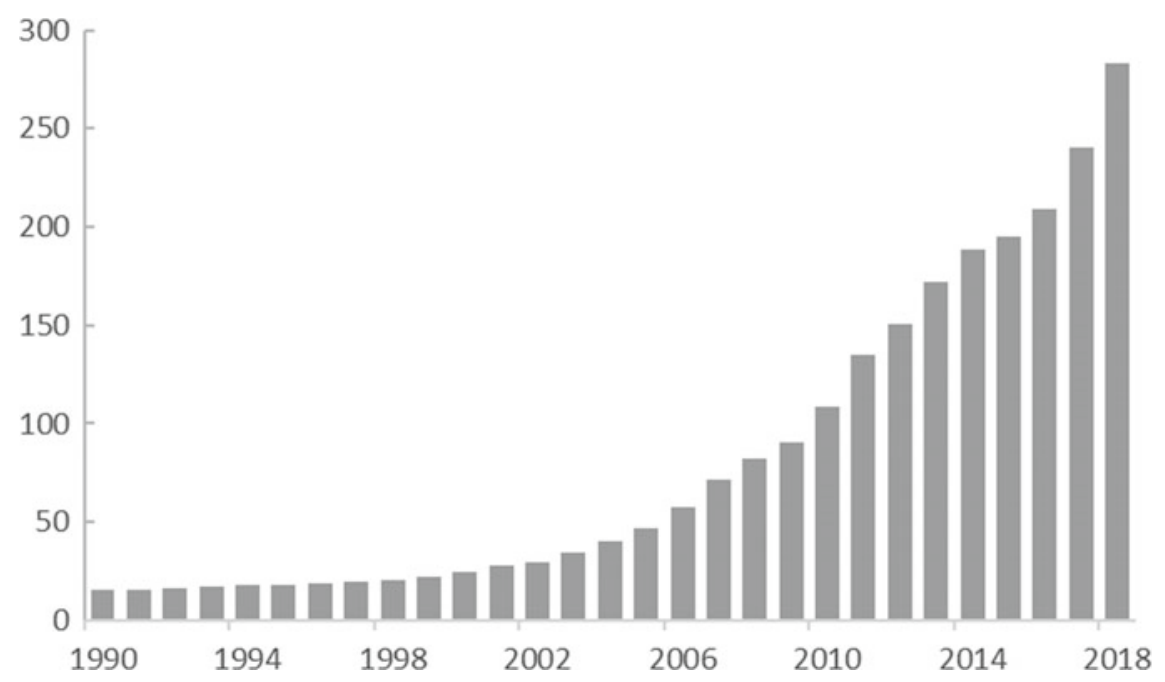

Fig. 3 China's natural gas demand, BCM. Source NDRC, BP

\subsection{China's 'Energy Revolution': The Nexus Between Energy and Technology}

China's 12th FYP ushered in more than a change in energy policy priorities. It was designed to address the "Four "Uns", as articulated by former Premier Wen Jiabao, and change course for an economy that was deemed 'unstable, unbalanced, uncoordinated and unsustainable'. As such, it also saw the convergence of China's industrial upgrade plan and its energy priorities. In mid-2014, the country announced an 'energy revolution', which was later formalised in a publicly released policy paper setting out the main overall targets and strategies for China's energy sector through 2030 (NDRC 2016). The energy revolution spans energy consumption, by mandating demand-side management for industry and changing consumer habits; energy production-calling for enhancing efficiencies and reducing emissions from China's energy infrastructure and energy technology and also includes an effort to develop, commercialise and diffuse next-generation energy technologies through innovation and international cooperation.

In the context of China's industrial programme, climate change mitigation became an opportunity for underpinning China's economic transition and a potential means of advancing China's bid for global technology leadership (Geall 2017). And given the country's scale and strong ability to incentivise industrial outcomes, it has proven capable of rapidly driving change. The 12th FYP highlighted seven strategic emerging industries that would receive preferential support, including renewable energy technologies and electric cars. The subsequent plan, the 13th Five-Year Plan (13th FYP; 2016-2020), continues the emphasis on clean technologies, although it aims to 
give the market, rather than state subsidies, a determining role in selecting the most competitive green industries and technology leaders (Geall, 2017).

China has since become the global leaders in renewables. In 2012, China's installed capacity of wind and solar power was $61 \mathrm{GW}$ and $3.4 \mathrm{GW}$, respectively, while the annual electricity generated by renewables was only $2.1 \%$ of China's total consumption. By 2017, China's wind and solar power capacity had increased to 168.5 GW and $130.06 \mathrm{GW}$, respectively, and renewables were generating 5.3\% of China's electricity supply (Linster and Yang 2018). Installed solar capacity has outstripped the $110 \mathrm{GW}$ targeted in the 13th FYP, with $186 \mathrm{GW}$ installed in June 2019. Similarly, wind capacity is largely on track to meet its 13th FYP target of $210 \mathrm{GW}$ of installed capacity, having reached 193 GW in June 2019.

On the back of increased manufacturing capabilities, the average price of global PV modules decreased by $79 \%$ from 2010 to 2017 . At the same time, the subsidy programme was draining central government coffers, with the total amount of wind and PV subsidies in 2017 estimated at about 170 billion yuan (Lin and Yang 2018) and a source of global trade friction, as Chinese manufactured solar PV modules were the target of anti-dumping measures. But ultimately, Chinese companies' ability to reduce costs and support investments globally in the 'low carbon' economy have supported wider efforts to tackle climate change (Goron 2018).

Moreover, since 2015, China has invested over US\$100 billion a year in domestic renewable energy projects, almost double the US's \$64 billion in 2018 (BNEF 2019). Of over 8 million renewable energy jobs globally, 3.5 million were in China in 2015 and the Chinese government estimates that between 2016 and 2020, new investments in renewables will create 13 million jobs (Jaeger et al. 2017). China has therefore been driving global renewables consumption growth, both by installing capacity at home and exporting solar panels and wind turbines. As such, China's decarbonisation goals and commitment to the UN climate process are consistent with and supportive of its key economic and technological ambitions, namely, the domestic economic rebalancing away from energy-intensive heavy industries towards innovation and services. Moreover, increasing the share of renewables in the energy mix also supports China's energy security by reducing import dependence and limiting the effects of geopolitical conflict or price volatility on energy supply.

\section{Climate Leader or Climate Villain?}

China's commitment to its 'energy revolution' suggests that renewables will account for a growing share of the country's energy use while supercharged efforts to spur innovation are already turning Chinese companies into global leaders in the technologies underpinning the energy transition. To date, China's domestic efforts have altered the country's international position markedly, too. China was cast as the villain of global climate talks in Copenhagen in 2009, but has become an active participant, if not a de-factor leader, in climate diplomacy especially since President Trump's decision to withdraw from the Paris agreement created a leadership 
vacuum. The commitments to rebalance the Chinese economy, phase out coal gradually and develop energy technologies suggest that China will stick to its pledges. Whether or not China voluntarily assumes climate leadership globally is perhaps a moot point, but the technological and economic changes within China suggest that it will inevitably play a more prominent role globally. That said, how China is perceived globally will depend not only on its exports of clean energy but also on how it manages its own energy transition. There are already signs that China could become both a climate leader and villain, with respect to its domestic energy consumption and its overseas investments.

\subsection{Electrification Before Decarbonisation}

It is important to note that China's 'energy revolution' emphasises air quality, rather than carbon mitigation, with mandatory targets to reduce air pollutants such as $\mathrm{SO}_{2}$ and NOx with less emphasis on greenhouse gas emissions more broadly. The plan also reiterates China's climate change commitments undertaken in the Paris framework, to peak $\mathrm{CO}_{2}$ emissions around 2030 or earlier, and to reduce carbon emission per unit of GDP by 60-65\% compared to 2005, without, however, setting an absolute cap for carbon emissions. Put simply, China's air quality and climate policies have been developing relatively autonomously from each other with air pollution the main source of concern for the Chinese government. Air pollution is perceived as an environmental problem, while climate change has been framed as a development issue and until March 2018, each policy was under the supervision of different parts of the state administration (Yamineva and Liu 2019).

In addition, China's energy transition is at the intersection of a number of policy priorities whose relative importance for decision-makers can fluctuate. In 2019, for example, given the decelerating economy and a weak industrial complex, air pollution woes are falling slightly in importance, in large part because the largest polluters are impacted by the economic moderation. So, costly efforts to mitigate air pollution, such as the coal-to-gas switch, are also slowed. At the same time, given the ongoing trade war with the US, concerns about supply security and import dependence are resurfacing. It is perhaps too early to tell, at the time of writing, whether China's economic slowdown and its frictions with the US are secular rather than structural trends and while a number of long-standing policy priorities, such as the economic rebalancing and the adoption of cleaner energy, will maintain their importance, the speed and scope with which they will be pursued will depend on these macroeconomic and geopolitical trends.

When considering China's future energy mix, there are a host of possible scenarios, which suggest dramatically different demand profiles for China. On one hand, China's National Renewable Energy Center (CNREC 2018) estimates that under current policy guidelines, China's fossil fuel consumption can peak in 2020 and decline gradually through 2035. By 2035, the share of coal in the energy mix would be just over $10 \%$ as its use in the power and industrial sectors would fall. At the same 


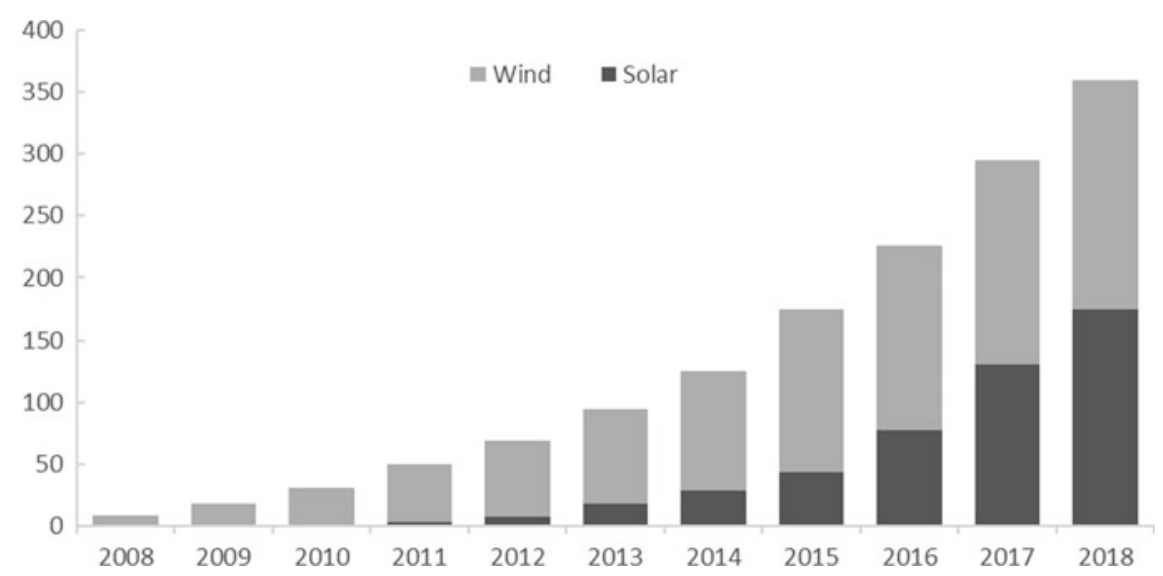

Fig. 4 Installed renewable capacity, GW. Source China Electricity Council

time, oil demand would also begin to decline due to higher levels of electrification in transport and industry. And with the rise of renewable energy, China would not need gas to serve as a bridge between coal and renewable energy. With improved economics, according to the CNREC, China could require an additional 80-160 GW of new solar PV installation and 70-140 GW of new wind capacity per year. Such an aggressive rollout likely assumes that China manages to overcome a number of challenges, related to the rigidity of the domestic electricity market (Chen 2017) and to develop the intelligent infrastructure required for its effective deployment (Fig. 4).

Indeed, CNREC considers an even more aggressive scenario whereby coal consumption falls even further, thanks to a faster adoption of renewables, but these scenarios should be contrasted with how China's fossil fuel industry views the country's energy future. CNPC, China's largest oil and gas company, in its 2050 outlook, expects primary energy demand to peak between 2035 and 2040 (CNPC 2016) and while the share of coal in the energy mix will continue to fall through to 2050, in 2035 coal will still account for roughly a third of primary energy demand. Indeed, absolute demand for coal is expected to remain at 2018 levels until 2025, given its importance in power generation. CNPC sees coal's share of the energy mix continue its decline but it will still remain the single largest supply source through to 2050 . In power generation, according to CNPC, coal is set to peak only in 2030 and even as industrial coal use declines after 2030, coal in petrochemicals will offset some of that fall (Fig. 5). To be sure, falling costs of renewables and reforms in the Chinese power sector could allow for the more progressive scenarios in China to materialise, but in the near term, the country may well electrify much faster than it can decarbonise. China's international stance will look very different in each of the above scenarios, and its domestic demand for clean energy technologies and equipment will also determine the availability and price of exports. 


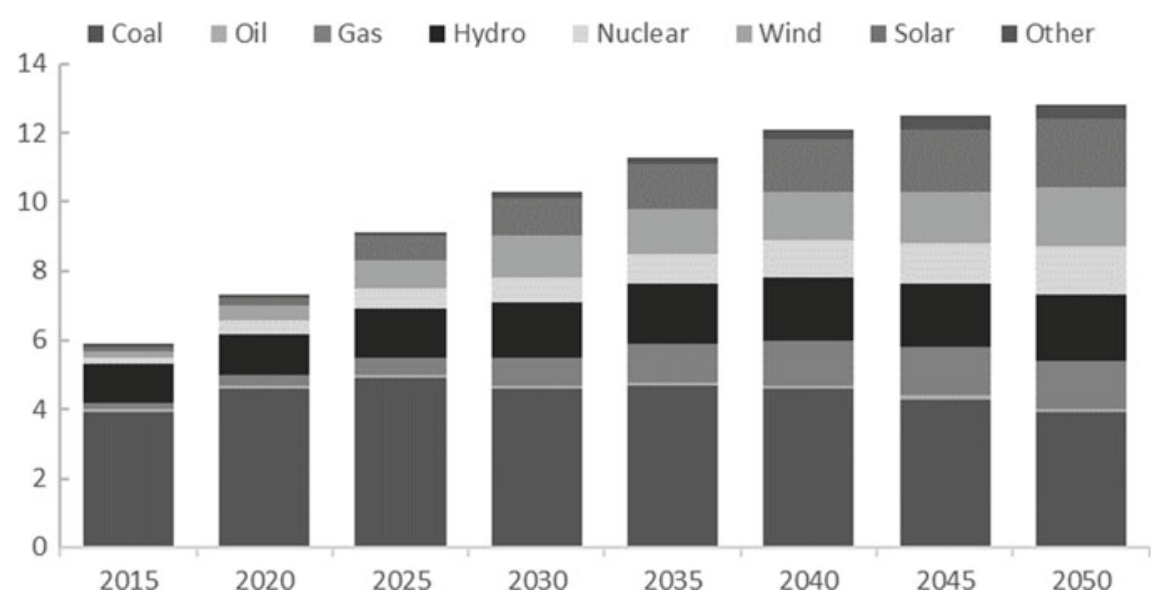

Fig. 5 China's power demand forecast, trillion kwh. Source CNPC

\subsection{China Commercialises and Exports Clean Tech}

By virtue of China's scale, the rapid ramp-up of renewables in the country has catapulted Chinese companies' status globally. Chinese solar manufacturers account for about $60 \%$ of global solar cell production, with a recent ranking suggesting also that these manufacturers are also among the highest quality manufacturers globally (Geall 2017). Similarly, China in 2018 was the largest wind market (for both onshore and offshore), leading Chinese manufacturers to capture almost half of the global market (Lacal-Arántegui 2019) yet when discounting installations in China, European manufacturers remain more dominant globally. Indeed, while Chinese companies have also helped cost reductions globally, research suggests that they experience difficulties when developing global products and competing in terms of innovation. Chinese firms mainly file patents in the domestic markets but seem to have limited innovation competitiveness globally (Cao et al. 2018; Pan et al. 2019). Whether China is a leader or a follower in renewable energy manufacturing remains a topic of debate (Tyfield et al. 2014), but it is still undoubtedly the biggest investor in cleantech and the largest market, capable of commercialising new energy products. Globally, China has invested an estimated \$44 billion in clean energy projects in 2017 (IEEFA 2018), and the International Energy Agency forecasts China will build $40 \%$ of the world's wind energy capacity and 36\% of global solar capacity from 2015 to 2021.

China's largest power utility, State Grid Corporation has followed in the renewable manufacturers' footsteps to expand its global reach. Within China, State Grid's investment in long-distance high-voltage power transmission lines has been an important factor in alleviating some of China's curtailment issues. State Grid has also set out its vision of creating a global supergrid called the 'Global Energy Interconnection' (GEI) that aims to link every continent with undersea transmission cables to 
power the world with green electricity (IRENA 2019). In the interim, however, State Grid focuses on smaller scale projects globally.

Beyond exports of renewable energy infrastructure, China's efforts to increase energy efficiency at home have brought it to the forefront of new technologies driving efficiency gains. China now accounts for roughly half the global market for energy service companies, including connected devices which allow real-time control of energy consumption. China is now the largest market for smart metres, having installed more than 500 million (IEEFA 2018), and ongoing progress in developing connected devices and smart energy management systems will gradually allow it to expand its global footprint, much like it is currently doing with lithium-ion batteries and electric vehicles.

China's lithium-ion battery production capacity is growing rapidly, supported by Beijing's goal of making China the leading country in the global EV supply chain. Chinese companies are expected to hold 121 gigawatt-hours (GWh) of battery production capacity by 2020, dwarfing Tesla's 35 GWh (IEEFA 2018). Already in 2016, an estimate of 200 energy storage manufacturers produced a combined capacity of $120 \mathrm{GWh}$ of energy storage that is scheduled to be operational by 2018 . That year, China's lithium-ion battery shipments increased by $80 \%$ year on year (Vorrath 2017).

More broadly, both Chinese companies and Beijing are focusing on energy storage solutions. In October 2017, the Chinese government issued its first national policy document guiding the energy storage industry, outlining two stages of development through 2027. The policy document views the first phase running through 2022, during which domestic storage technology production to reach advanced international standards, with preliminary accomplishments in creating a standards body. Subsequently, throughout the 14th FYP, China aims to develop a mature industry with world-class, internationally competitive technology. Subsequently in 2018, the government announced a major storage push to help address curtailment of domestic renewable energy generation, followed by an additional two-year action plan in 2019-2020 to support R\&D in energy (NDRC 2019). Under the programme, the government will issue subsidies to encourage the construction of energy storage facilities and support trials of new storage technology testing pumped hydro storage, compressed air storage, magnetic energy storage and large-scale battery storage deployments. The Chinese government aims to maintain domestic manufacturing control over the whole supply chain for energy storage-from raw materials, battery technology and supercapacitors to micro-grid and smart-grid equipment.

While battery and storage technologies are critical elements of the energy transition, they are also a key component in electric mobility. Electric car manufacturers have been identified by the Chinese government as potential 'indigenous innovation' rivals for incumbent auto-manufacturers and with strong incentive schemes, China in 2018 was the largest electric vehicle market globally (IEA 2019) with a stock of 2.3 million units; it accounted for almost half of the global electric cars, having sold 1.1 million electric cars that year. China is also the largest market globally for electric two- and three-wheelers and for low-speed electric vehicles (LSEVs), estimated at 5 million units. Yet the EV fleet consumed an estimated 58 terawatt-hours (TWh) of electricity in 2018, with China accounting for $80 \%$ of that demand. 
These latest data points highlight a number of unique facets of cleantech diffusion in China: regardless of whether Chinese companies are leaders or followers in innovation, strong government backing allows them to commercialise new products rapidly. Moreover, disruptive innovation has emerged in China from lower tech products, including electric two-wheelers and LSEVs, defying government policies (Zhou et al. 2018) and escaping the reach of high-tech innovation in large firms (Tyfield 2014). Chinese cleantech companies could therefore export a wide array of products to both developed and less affluent markets.

\subsection{How Green Are the Belt and Road?}

One case in point is China's Belt and Road initiative (BRI), the country's multibilliondollar infrastructure investment plan. Overseas investments under the auspices of the BRI have the potential to transform global development towards lower carbon alternatives, as seen in the above examples, but it could also lock in high-carbon growth in developing countries. Ironically, while China's domestic oversupply of solar panels led to a fall in global prices (and related concerns about China's trade practices) through 2016, the country's record-breaking solar buildout in 2017 absorbed much of the country's module output, leading to higher prices for international customers (IEEFA 2018).

Recent research highlights that between 2000 and 2016, 66\% of power sector lending from Chinese banks went into coal projects. China was involved in 240 coalfired power projects in 25 of the 65 Belt and Road countries, with a total installed capacity of $251 \mathrm{GW}$. Chinese financial institutions have committed or offered funding for over one-quarter (102 gigawatts GW) of the 399GW of coal plants currently under development outside China (IEFFA 2019), including investment in export coal mines, coal-fired power plants, and the associated rail and port infrastructure in countries including Vietnam, South Africa, Pakistan and Indonesia. Yet, there is a growing divergence between state-backed financing and private funding. From 2014 to 2017, more than two-thirds of China's energy-sector loans and investments (through banks, policy banks and state-owned companies) were in fossil fuels (Zhou et al. 2018), while nearly two-thirds (64\%) of cross-border energy-sector investment by Chinese privately owned enterprises were in renewable energy.

Going forward, China's global energy investments will likely be determined by a number of factors, including the state of the domestic market, companies' desire to expand their global footprint, and the pull from host countries (Downs 2019), but barring a radical shift in global demand-i.e. that host countries push back against investments in coal-fired power plants as they have rejected hydropower investments-China's energy exports will both help and hinder the global energy transition.

A final factor determining China's exports will be its ongoing tussle with the US. As the US-China trade war escalates into a deeper geopolitical and commercial rivalry, China's clean energy investments, especially to the extent that they could 
begin to set global standards in energy management for example, could become a source of geopolitical friction.

\subsection{The US and China: A Quest for Technological Dominance}

The trade war between the US and China has highlighted a paradigm shift in USChina relations that is increasingly shaping China's energy policies and in extension, the global ramifications of its energy transition. The US Department of Defense's latest Indo-Pacific Strategy paper, for example, highlights the 'geopolitical rivalry between free and repressive world order visions' (US Department of Defense 2019). Officials in the US administration including Vice President Mike Pence and Secretary of State, Mike Pompeo have issued increasingly hawkish speeches regarding China's economic statecraft and accusing it of becoming increasingly aggressive and destabilising. This has vindicated those in China that have argued that the US is aiming to contain China's rise, and while the 'decoupling' narrative is not endorsed by Chinese officials, advisers and strategists (Wang 2019) are contemplating what a commercial Cold War could look like (Meidan 2019).

Up until the trade war, closer US-China relations led to an integration of goods, capital, technology and people, with a view that this economic integration would mitigate security competition. But the trade war and the US ban on Chinese telecom giant Huawei in May 2019 are threatening to decouple supply chains, especially those that use sensitive technology. Indeed, even if the Huawei ban is lifted, from China's perspective, the US's ability to cut off tech companies from their supply chains has been made abundantly clear.

A similar case in point is the US designation of Chinese companies for trading with Iran. US sanctions on two subsidiaries of China's largest shipping company, COSCO Shipping Energy, in October 2019 led Western companies to shun all COSCO assets, regardless of the ownership structure, for fear of being caught up in US secondary sanctions. Given these precedents, governments and businesses must now prepare for the possibility that a Chinese supplier or partner with which they work could be sanctioned by the US government, offering initial glimpse of de-globalisation of trade flows and even of technology (Rosset 2019). The takeaway in China has been that it must indigenise as much as it possibly can. So, even if the 'Iron curtain' on technology (Paulson 2018) will not materialise, it is no longer a mere fantasy. The race between the US and China is increasingly beyond a competition for better quality technological innovation, but also for standard setting. 


\subsection{Controlling Critical Resources}

The rising mistrust of the US has also made China acutely more aware of its reliance on global resources and supply chains. Oil and gas markets are seen to be dominated by Western companies and US financial institutions, while sea lanes of navigation are effectively dominated by the US. Not only do commodities transact in US dollars (for the most part) but also US naval supremacy - which in many parts of the world as a provision of global goods (i.e. uninterrupted flows) — is an existential threat from Beijing's point of view, as it could be used by the US as a means of cutting off vital supplies from China. China's growing appetite for imported energy has confronted the country with the insecurity of its energy supplies. The Chinese government has deployed vast resources in a bid to hedge against these vulnerabilities with varying degrees of success.

The energy transition, however, brings with it demand for new types of resources. Rapid growth in EVs has boosted demand for metals used in power batteries, such as lithium, nickel, manganese, cobalt, tungsten, magnesium and rare earth. Production of these metals is heavily concentrated among a relatively small number of companies and in a handful of countries. Roughly, half of the global cobalt supplies, for example, are located in the conflict-prone Democratic Republic of Congo (DRC). China relies on the DRC for around $80 \%$ of its cobalt imports, but it has also effectively established a monopoly over output in the DRC as well as over intermediate and refined cobalt (Gulley et al. 2019).

Rare earths are another case in point. While most of the 17 rare earth minerals are not geologically rare, they are expensive and polluting to mine and produce, leading the US to limit production and allowing China to rise to predominance over rare earth production since the 1990s. Beijing has also shown its willingness to use rare earths exports as a geopolitical tool when in 2012, it issued export restrictions on rare earth. To be sure, the subsequent rise in prices and fears about China's dominance led to investments in additional resources globally. Moreover, efforts are being made to create cobalt-free batteries, and only a small minority of wind turbines (less than $2 \%$ in the US) are built with rare earth elements. Some minerals can also be recycled, re-used and stockpiled, thereby further reducing their perceived scarcity (Quiggin, 2017).

Nonetheless, by taking the lead on renewables, China has improved its geopolitical standing in several respects. By producing more of its own energy, China is reducing its reliance on fuel imports and the risks of energy disruption which could put a brake on its economic ambitions. Its technological expertise in renewables has established it as a leading exporter of clean energy technology and could help cement the country's technological dominance.

Moreover, China's investments along the BRI, namely, its investments in power grids could shape the geopolitics of energy in new and profound ways. While the US has shaped and safeguarded fossil fuel trading routes, China could shape power networks going forward. Infrastructure links and the Internet may become new battlegrounds for influence and control between competing powers (IRENA, 2019) with 
inter-state electricity cut-offs becoming a foreign policy tool, akin to pipeline politics or sanctions.

Notably, however, electricity trading tends to be more reciprocal than trade in oil and gas. So cross-border electricity trading will create opportunities for regional cooperation, and the creation of 'grid communities'.

\section{A Brave New World}

China's emergence as a global economic power and energy consumer in the early 2000s altered the geopolitical landscape of oil and gas. The scale of Chinese demand growth boosted fossil fuel production and trading, but also raised alarm bells in Beijing about the strategic vulnerabilities associated with its strong appetite for imports. Concerns about import dependence were gradually overshadowed by the rising cost of environmental degradation. Yet as China has sought to rebalance its economic structure and rise up the industrial value chain, government-supported efforts to spur innovation are already turning Chinese companies into global leaders in the technologies underpinning the energy transition. Beijing has also been able to capitalise on these gains to become a global leader on climate. Yet, China's track record is extremely mixed. It is the fastest growing renewables market globally and is also the biggest market for electric mobility in the world, but coal is now and will remain for the foreseeable future an intrinsic part of the Chinese energy mix.

In its overseas investments, China is fuel-agnostic and technology-agnostic, willing to finance and sell both coal-fired power plants and clean energy equipment and solutions. The scope and speed with which China chooses to pursue its own energy transition will remain a key variable in the global energy shift. Indeed, China is unique in its efforts to decarbonise before it has fully industrialised. As such, China could electrify its energy use before it decarbonises power. Indeed, despite China's commitment to tackling toxic air quality and climate change, it is still committed to domestic growth and development. To the extent that coal can offer stable, secure and cheap energy, it will remain a component of China's energy mix.

As the gulf between the US and China deepens, these contradictions will become increasingly visible. China may look to slow its shift away from coal while also accelerating its efforts to become a global leader in clean technologies. As part of its industrial policy, Beijing will continue to promote the indigenisation of clean technology as well as research into disruptive innovation. Chinese companies may become both technology followers and leaders, given the size and scope of the market. Some innovation will be catered to domestic needs and may find welcoming export markets in developing countries but increasingly, as the competition with the US intensifies, China is already controlling supply chains and shaping the infrastructure critical to the energy transition. 


\section{References}

Asian Infrastructure Investment Bank (AIIB) (2017) President Jin Liqun, Opening address as prepared for delivery at the Meeting of the AIIB Board of Governors, 16 June 2017, https://www. aiib.org/en/news-events/news/2017/20170616_002.html

Bloomberg New Energy Finance (BNEF) (2019) Clean Energy Investment Exceeded \$300 Billion Once Again in 2018, 16 January 2019, https://about.bnef.com/blog/clean-energy-investmentexceeded-300-billion-2018/ accessed 25 October 2019

Boqiang L (2018) China is a renewable energy champion. But it's time for a new approach, World Economic Forum, https://www.weforum.org/agenda/2018/05/china-is-arenewable-energy-champion-but-its-time-for-a-new-approach/

BP Statistical Review of World Energy (2019) https://www.bp.com/en/global/corporate/energyeconomics/statistical-review-of-world-energy.html. Last accessed 28 October 2019

Cao X, Rajarshi A, Tong J (2018) Technology Evolution of China's Export of Renewable Energy Products. International Journal of Environmental Research and Public Health, 15(8). https:// www.ncbi.nlm.nih.gov/pmc/articles/PMC6121901/. Last accessed 15 October 2019

ChinaPower (2016) "Is air quality in China a social problem?", February 15, 2016. Updated October 16, 2018. Accessed October 28, 2019. https://chinapower.csis.org/air-quality/

Jinqiang Chen 2017, "The Challenges and Promises of Greening China's Economy", Belfer Center Discussion Paper, https://www.belfercenter.org/publication/challenges-and-promises-greeningchinas-economy, accessed August 2019

Erica Downs 2004, "The Chinese Energy Security Debate", The China Quarterly, no. 177

Erica Downs, 2019, "China-Pakistan Economic Corridor Power Projects: Insights into Environmental and Debt Sustainability", https://energypolicy.columbia.edu/research/report/china-pakistaneconomic-corridor-power-projects-insights-environmental-and-debt-sustainability, accessed 23 October 2019

Ely Adrian, Geall Sam, Dai Yixin (2019) Low carbon China: emerging phenomena and implications for innovation governance - introduction to the special section of environmental innovation and societal transitions. Journal of Environmental Innovation \& Societal Transitions 30:1-5

Institute for Energy Economics and Financial Analysis (IEEFA) 2018, "China 2017 Review: World's Second-Biggest Economy Continues to Drive Global Trends in Energy Investment", http://ieefa. org/wp-content/uploads/2018/01/China-Review-2017.pdf

Sam Geall, 2017, "Clear Waters and Green Mountains: Will Xi Jinping Take the Lead on Climate Change?", Lowy Institute Analysis Paper, https://www.lowyinstitute.org/publications/clearwaters-and-green-mountains-will-xi-jinping-take-lead-climate-change, accessed 10 September 2019

Goron Coraline (2018) Fighting against climate change and for fair trade: finding the EU's interest in the solar panels dispute with China. China-EU Law Journal 6(1-2):103-125

Andrew L.Gulley, Erin A.McCullough, Kim B.Shedd, 2019, "China's domestic and foreign influence in the global cobalt supply chain", Resources Policy, pp. 317-323

IEA (2019), "Global EV Outlook 2019”, IEA, Paris, www.iea.org/publications/reports/ globalevoutlook2019/

IRENA, 2019, "A New World: The Geopolitics of the Energy Transition", http:// geopoliticsofrenewables.org/assets/geopolitics/Reports/wp-content/uploads/2019/01/Global_ commission_renewable_energy_2019.pdf

Joel Jaeger, Paul Joffe and Ranping Song, 2017, "China is Leaving the U.S. Behind on Clean Energy Investment", January 06, 2017, https://www.wri.org/blog/2017/01/china-leaving-usbehind-clean-energy-investment

Linster and Yang, 2018, "China's Progress Towards Green Growth: an international perspective", OECD Green Growth Papers, No. 2018/05, OECD Publishing, Paris, http://www.oecd.org/env/ country-reviews/PR-China-Green-Growth-Progress-Report-2018.pdf, last accessed September 2019

Meidan M (2014) The Implications of China's Energy-Import Boom. Survival 56(3):179-200 
Meidan M, Andrews-Speed P, Xin Ma, 2009 Shaping China's Energy Policy: actors and processes, Journal of Contemporary China, 18:61, 591-616, Shaping China's Energy Policy: actors and processes. Available from: https://www.researchgate.net/publication/248999566_Shaping China's_Energy_Policy_actors_and_processes [accessed Oct 28 2019]

Miyamoto A, Ishiguro C (2018) "The Outlook for Natural Gas and LNG in China in the War against Air Pollution", OIES Paper, NG 139, https://www.oxfordenergy.org/wpcms/wp-content/uploads/ 2018/12/The-Outlook-for-Natural-Gas-and-LNG-in-China-in-the-War-against-Air-PollutionNG139.pdf?v=79cba1185463, accessed October 2019

Myllyvirta L (2019a) Why China's CO2 emissions grew 4 percent during first half of 2019, Carbon Brief, 5 September. https://www.carbonbrief.org/guest-post-why-chinas-co2-emissions-grew-4during-first-half-of-2019, last accessed Oct 28, 2019

NDRC (2016) 能源生产和消费革命战略 (Energy Supply and Consumption Revolution Strategy (2016-2030). http://www.ndrc.gov.cn/gzdt/201704/W020170425548780357458.pdf. Last accessed 10 October 2019

NDRC (2019) 关于促进储能技术与产业发展的指导意见 2019-2020年行动计划2019-2020 Action Plan to Guide the Technological and Industrial Development of Energy Storage Sector, http://www.ndrc.gov.cn/zcfb/zcfbtz/201907/t20190701_940747.html

P M, Dillon YZ, Zhou K (2019) Comparing the innovation strategies of Chinese and European wind turbine firms through a patent lens. Environmental Innovation and Societal Transitions 30:6-18

Paulson (2018) Remarks by Henry M. Paulson, Jr., on the United States and China at a Crossroads', 6 November 2018, http://www.paulsoninstitute.org/news/2018/11/06/statement-byhenry-m-paulson-jr-on-the-united-states-and-china-at-a-crossroads/

Quiggin D (2017) Scrapping the combustion engine: the metals critical to success of EVs, 28 July 2017

Ramaswami A, Tong K, Fang A, Lal RM, Nagpure AS, Li Yang, Huajun Y, Jiang D, Russell AG, Shi L, Chertow M, Wang Y, Wang S (2017) Urban cross-sector actions for carbon mitigation with local health co-benefits in China. Nature Climate Change 7:736-742

Rosset C (2019) Huawei Ban Means the End of Global Tech. Foreign Policy, 17 May 2019. https://foreignpolicy.com/2019/05/17/huawei-ban-means-the-end-of-global-tech/, accessed 19 September 2019

Tyfield D, Zuev D, Ping L, Urry J (2014) Low Carbon Innovation in Chinese Urban Mobility: Prospects, Politics and Practices. STEPS Working Paper 71

US Department of Defense (2019) Indo-Pacific Strategy Report Preparedness, Partnerships, and Promoting a Networked Region. Accessed 1 June 2019 from https://media.defense.gov/2019/ Jul/01/2002152311/-1/-1/1/DEPARTMENT-OF-DEFENSE-INDO-PACIFIC-STRATEGYREPORT-2019.PDF, p. 4

Wang O (2019) Chinese economists warn Beijing to prepare for decoupling from US. South China Morning Post, 7 July 2019. https://www.scmp.com/news/china/article/3017550/chineseeconomists-warn-beijing-prepare-decoupling-us

World Bank (2019). https://data.worldbank.org/country/china?view=chart

Yamineva Y, Liu Z (2019) Cleaning the air, protecting the climate: Policy, legal and institutional nexus to reduce black carbon emissions in China. Environ Sci Policy 95:1-10

Zhou L, Gilbert S, Wang Y, Cabré MM, Gallagher KP (2018) Moving the Green Belt and Road Initiative: From Words to Actions, World Resources Institute. https://www.wri.org/publication/ moving-green-belt-and-road-initiative-from-words-to-actions 
Open Access This chapter is licensed under the terms of the Creative Commons Attribution 4.0 International License (http://creativecommons.org/licenses/by/4.0/), which permits use, sharing, adaptation, distribution and reproduction in any medium or format, as long as you give appropriate credit to the original author(s) and the source, provide a link to the Creative Commons license and indicate if changes were made.

The images or other third party material in this chapter are included in the chapter's Creative Commons license, unless indicated otherwise in a credit line to the material. If material is not included in the chapter's Creative Commons license and your intended use is not permitted by statutory regulation or exceeds the permitted use, you will need to obtain permission directly from the copyright holder.

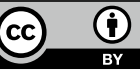

